\title{
INTEGRATING WORKPLACE SPIRITUALITY, TOTAL QUALITY MANAGEMENT, AND JOB SATISFẢCTION
}

\author{
Wiwiek Rabiatul Adawiyah* \\ Universitas Jenderal Soedirman \\ Ratno Purnomo \\ Universitas Jenderal Soedirman \\ Bambang Agus Pramuka \\ Universitas Jenderal Soedirman \\ Zahrotush Sholikhah \\ Universitas Negeri Yogyakarta
}

\begin{abstract}
TQM needs comprehensive refashioning of "softer" methods whose components encompass the core concept of personnel management to be entirely practical and self-sustaining. The alleged usefulness of the people aspect of TQM's is essential than its technical side in influencing the presumed utility of customers. Thus, the successful execution of TQM programs profoundly depends on the motive, abilities, engagement, and rolepowers of the participants in an organization. TQM is not just about solving problem but more about satisfying clients. Hence, this study investigated the interaction effect of soft Total Quality Management, employees' Job Satisfaction and spirituality at work. The respondents were employees of Islamic banks in Indonesia. The hierarchical regression was considered to be the most appropriate analytical tool used for data analysis in this study. The findings showed that all dimensions of soft total quality management had a detrimental effect on job satisfaction. Moreover, stronger employees' spirituality at work strengthen the association between soft TQM dimensions, except empowerment, with job satisfaction.
\end{abstract}

Keywords: Islamic banks; Soft TQM; Workplace spirituality; Job satisfaction; Indonesia.

Received: 16 January 2018

Accepted: 20 May 2020

\section{INTRODUCTION}

Globalization has posed several business issues, such as high-speed motion, and borderless competition, which requires prompt retort. The business atmosphere is dynamically escalating, emphasized by a vigorous business milieu, and fast-changing technological advances (Helmy, Adawiyah, \& Banani, 2019; Wihuda, Kurniawan, Kusumah, \& Adawiyah, 2017). Every

\footnotetext{
* Corresponding author: Wiwiek Rabiatul Adawiyah, Faculty of Economics and Business, Universitas Jenderal Soedirman, Jl. HR Boenyamin, Purwokerto, Central Java, Indonesia. E-mail address: wiwiekra@gmail.com
} 
organization must unlock its most excellent strategy to survive the onslaught of business competition. TQM is conceived as a auspicious response to the competitiveness issue (Latif, Iqbal, ur Rehman, Latif, \& ur Rehman, 2014). Over the last two centuries, management knowledge has evolved remarkably, and Total Quality Management has been implemented (Adawiyah \& Pramuka, 2012; Eniola, Olorunleke, Akintimehin, Ojeka, \& Oyetunji, 2019; Hendricks \& Singhal, 1996; Othman, Norfarahhanim Mohd Ghani, \& Woon Choon, 2019). For instance, Hendricks and Singhal (1996) offer an extensive summary of Total Quality Management issues claiming that voluminous companies are taking the initiative in encouraging Total Quality Management by offering high-quality prizes to businesses that achieve exceptional quality.

Despite the large-scale support of TQM, its value creation potential has been significantly skeptical (Adawiyah \& Pramuka, 2012; Adebanjo \& Kehoe, 1999). There is a prevailing difference in TQM's real ability to improve an organization's efficiency (Latif et al., 2014). Although scientists alleged the absence of uniformity between the TQM procedures and other leadership elements, they hardly offer comprehensive theory or unbiased empirical evidence for their findings. Above all, little or nothing proof shows the extent to which this inaccuracy affects the effective execution of the TQM programs (Othman et al., 2019; Soltani, 2003; Soltani, Gennard, Van der Meer, \& Williams, 2004). Moreover, there is shortage of available empirical research to substantiate a clear relationship between the human side of TQM with employee behavior at work (Pramuka and Adawiyah, 2012). TQM incorporates a comprehensive deep-rooted management teaching which advocates the beneficial bearing of TQM on job satisfaction (Morrow, 1997). Existing literatures reports indecisive findings apropos the impact of TQM on individual's performance.

Total Quality Management as a method, aimed at reducing the adverse personal factors effects against the efficiency and effectiveness of employee (Ehigie \& Akpan, 2006). TQM implementation requires employees' attitudes transformation to yield optimum outcomes. Nevertheless, individuals have a distinct way to cope with the vigorous organizational ambiance ( Sholikhah, Wang, \& Li, 2019; Warsito, Sholikhah, Adawiyah, \& Setyanto, 2020). Efficient change management must be ingrained in an ostensible perception of personal behavior, as the institutional change will foster a feeling of belonging, involvement, the route, and appreciation for uncertainties. As a popular managerial technique applied both by businesses and governments, TQM boost efficiency thereby increase profit.

The choice of profession is not arbitrary (Törnroos, Jokela, \& Hakulinen, 2019). People often choose to work in a place that fits their personality and value (Adawiyah, 2015; Kristof-Brown, Zimmerman, \& Johnson, 2005). The attraction-selection-attrition theory asserts that individuals are drawn to particular settings according to their arrangements and chosen by them (Schneider, 1987). Organizations with a healthy level of workplace spirituality experiencing increased skills and boost up of revenue. Spiritual based culture increases the physical and mental health of staff and enhance employee work intensity with higher outcomes. Blending workplace spirituality with TQM, as a revolutionized strategy, may result in favorable work outcome. Institutional recognition of employee's spirituality at work promotes fulfillment and outcomes, increased participation, lower enthusiasm for radicalization, and a proliferation in the organization's working time. Therefore, to be fully functioning, it is essential to incorporate the spiritual value at work in an attempt to commence the organizational revolution and restore social life balance (Hari Adi \& Adawiyah, 2018; Sholikhah et al., 2019). 
Comprehensive research on the relationships of TQM and job related attitudes in different contexts emerge in the literature (Boselie \& van der Wiele, 2002; Kabak, Şen, Göçer, Küçüksöylemez, \& Tuncer, 2014; Boon Ooi, Abu Bakar, Arumugam, Vellapan, \& Loke, 2007). However, there is still insufficient evidence in the framework of the Indonesian banking industry. The adoption of soft TQM in the banking industry elevate the organizational ability for market expansion (Latif et al., 2014). The establishment of Islamic banks is not only for-profit purposes but more towards popularizing the Islamic economic system. Although Muslim communities are the main clients, the banks serve their clients regardless their demographic and social backgrounds. Islamic banks consumers are rationalist who demand for excellent services. However, studies on the adoption of quality management in the banking sector, particularly in Islamic banks are still lacking. Therefore, this study is among the first attempt aiming at enhancing the theory in the field. A thorough thoughtfulness of the pivotal elements of quality management for the banking industry could be achieved through cross-sectional studies across nations.

After several years of TQM dominant, it may be helpful to conduct a study to see the alignment of workplace spirituality, total quality management and job satisfaction within spiritual based organization. Different geographical and cultural circumstances may influence the behaviors of workers (Hari Adi et al. 2017). The current inquiry is an effort to bridge the research discrepancy by incorporating TQM application in emerging nations in the existing literature. The result of this study add insight on the adoption of TQM in Islamic banks operating in a country with emerging economy.

\section{LITERATURE REVIEW}

\subsection{Soft TQM}

The first way to identify the idiom TQM is through comprehension of the term quality. In essence, the notion of quality is very subjective. The term quality can imply different things. Some see quality as "doing the right things right". The term stress on the importance of balancing expectations from three parties: external users - those people who purchase goods or utilize services offered by a company, shareholders and potential investors, and staffs as the internal customers (Adawiyah \& Pramuka, 2012). Although there are various dictions of the quality terms, none is widely accepted.

The dimensions of Total Quality Management can be broadly categorized into two: the soft side and the hard side of TQM (Powell, 1995; Rahman \& Bullock, 2005). Soft TQM also known as the human side of TQM, entails various aspects of human resources management (Adawiyah \& Pramuka, 2012; Dale, Cooper, \& Wilkinson, 1997; Rahman \& Bullock, 2005). Soft TQM relates specifically to companies effort to exhibit their devotion towards the human side of TQM comprising "customer focus," "leadership and top management commitment," "empowerment," "training and education," and "reward and recognition" - instead of the underlying theories of TQM (Pramuka \& Adawiyah, 2012). Meanwhile, Powell (1995) argue that 
hard TQM relates to elements such as lean manufacturing, control chart, six sigmas, and benchmarking.

Total quality management involves considerable refashioning of "softer" practices in the effort to be wholly self-sustain and successful (e.g., Dale et al., 1994; Rahman \& Bullock, 2005; Schonberger, 1994). Consequently, efforts to enhance performance should become an aspect of everybody's job, and the responsibility should be equally performed by everyone involved in organizations. Therefore, there is a necessity in the future to further evaluate organizational performance by measuring organizational workforces' achievements as well at the level of quality triumph of an organization.

\subsection{Job Satisfaction}

Employee satisfaction is among the most frequently observe topic in the human resources literature. Satisfaction illustrates an effective retort to particular components of the work or profession and suggests the pleasant or affirmative emotion that results from an evaluation of a person work life (Adawiyah, 2011; Morrow, McElroy, \& Scheibe, 2011; Ouyang, Zhou, Xiong, Wang, \& Redding, 2019). Job satisfaction is a dynamic state due to susceptibility against influence and modification from agents who come from either internal and external of an individual, a person's features and the immediate organizational milieu.

Employee ideas and innovation are the basis of thought and breakthrough. When work is not satisfactory, quality service and reliable products cannot be expected. Most TQM program include fresh quality strategy, fresh organizational buildings, fresh operational procedures, and different methods of evaluating efficiency. A question arises on the extent to which such TQM breakthrough impacts employees ' daily performance.

\subsection{Workplace Spirituality}

An exponential number of workplace spirituality publications have been very supportive of a job, institutional and spiritual partnership. Several scientists have suggested that the Cartesian division must be stopped to reflect a secular mind that makes a falsifiable distinction between spirit and physical flesh, assurance and confusion, concrete and vague (Adawiyah \& Pramuka, 2017; Rego, Pina E Cunha, \& Oliveira, 2008; Sholikhah et al., 2019). In addition, feelings, brain, sensations, emotions and physical organs collectively assist organizations to recognize society's role which is a thoughtful basis of accomplishment and even sustainability (Waddock, 1999). Some academics stress that rulers who have evolved spirituality are particularly efficient (Adawiyah \& Pramuka, 2017; Cacioppe, 2000; Fry, Vitucci, \& Cedillo, 2005; Sholikhah et al., 2019; Strack, Fottler, Wheatley, \& Sodomka, 2002).

Several scientists advocate spiritual rebellion as a matter of fact because work is gradually more critical for the personal growth of employees after the declining significance of faith, communities, and families (Adawiyah \& Pramuka, 2017; Sholikhah et al., 2019; Warsito et al., 2020). Other highlights that the spirituality in the workforce is healing of "modern leadership illnesses", a reminder of the faith between executives and employees, allegedly lost by insulated action, together with significant consequences of downsizing company, employee violence, and many other methods ignoring good psychosomatic habits (Fry et al., 2005) therefore adds results for 
companies (Hari Adi \& Adawiyah, 2018). Organization displays assessment, reciprocal consideration, and an awareness of the requirement of the employees by applying spirituality at its office. The workforce spends significant time working concerning their position, making them depend on workplaces for their primary connections with society (Adawiyah, 2015; Hari Adi \& Adawiyah, 2018).

\subsection{Quality, Spirituality and Job Satisfaction}

Employee is a source of ideas and information within organizations (Adawiyah, Pramuka, Najmudin, \& Jati, 2015). When work becomes unsatisfactory, quality service and reliable products cannot be expected. Despite that possibility, TQM program results are usually manifested in the manner of fresh quality strategies, fresh business processes, fresh organizational constructions, and fresh performance evaluation methods. Will these alterations affect the daily work of employees and hence their job satisfaction? Extensive studies in numerous context have been performed on the interaction between elements of total quality management and job satisfaction (Boselie \& van der Wiele, 2002; Kabak et al., 2014; Boon Ooi et al., 2007; Prajogo \& Cooper, 2010). However, there is a concern on the scarcity of literatures discussing on the impact Total Quality Management adoption by Islamic banks on their employee's job satisfaction.

Yet, the effectiveness of TQM implementation depends on perceptions or actions by employees at work. Therefore, organizations must concentrate on providing employees with excellent and meaningful work that promotes commitment, happiness, as well as self-worth Previous enquiry has confirm the association between the spirituality, passion, effort, fellowship, creativity, with employees favorable work outcomes (Adawiyah \& Pramuka, 2017; Milliman, Czaplewski, \& Ferguson, 2003). Individuals who choose career in line with their professional concerns, shall consistency contributes to higher fulfillment and improved results. Contrariwise, insolence and own estrangement would cause reduced employees' satisfaction and commitment. Personal-job fitness is recommended as a primary instrument for staff choice and maintenance and stronger fitness is linked to increased staff fulfillment and well-being (Kristof-Brown et al., 2005). Thus, authors proposed hypothesis are:

H: A Higher level of workplace spirituality shall strengthen the association between soft TQM and job satisfaction

Corollary hypotheses:

Ha: A higher level of workplace spirituality strengthens the association between leadership and top management commitment and employees' job satisfaction

$\mathrm{Hb}$ : A higher level of workplace spirituality strengthens the association between customers focus and employees' job satisfaction

Hc: A higher level of workplace spirituality strengthens the association between education and training and employees 'job satisfaction 
Hd: A higher level of workplace spirituality strengthens the association between empowerment and employees' job satisfaction.

He: A higher level of workplace spirituality strengthens the association between reward and recognition and employees' job satisfaction

Figure 1: Conceptual Framework

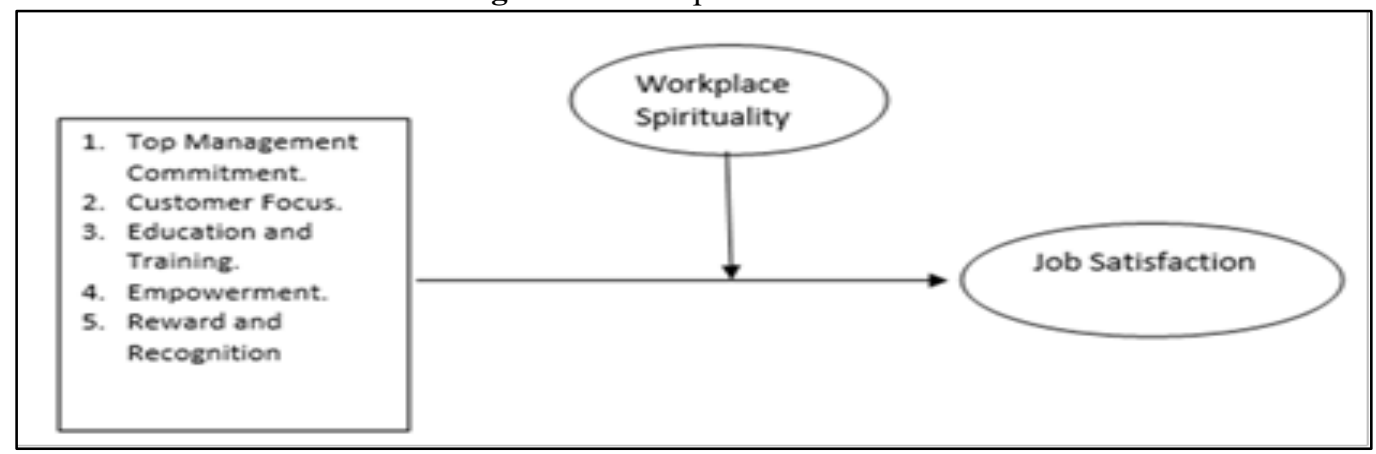

\section{METHODOLOGY}

\subsection{Sample}

Population of the study was employees of Islamic banks in Indonesia. The sample consist of Islamic banks employees located in Central Java Indonesia. Central Java is one of the Province in Indonesia with the greatest number of Islamic banks. The sample size was determined using Slovin's formula (1960) with a total number of distributed questionnaires was 950 (Slovin, 1960). Authors adopted the rule of thumbs, i.e. when the number of sample almost equal the population size, the normality of the data is ensured. For larger population, a sample size of 500 is good (Hair, Black, \& Babin, 2010) Similarly Tabachnick and Fidell (2007 p. 613), argued that the number that is considered "comfortable" if it above 300 cases, The overall completion level of distributed questionnaires was $89.47 \%$ (Tabachnick \& Fidell, 2007). Details of responses are exhibit in the Table 1. The participants consist of $62.5 \%$ work for Islamic Commercial Bank (ICB), 24.30\% work for Islamic Rural Banks (IRB), and 13.20\% work for Islamic banking units (IBU). Total of 497 or 58,47 thirds of 850 participants returning the questionnaires is used for information analytics.

Table 1: Description of Samples

\begin{tabular}{llcccc}
\hline \hline No & $\begin{array}{c}\text { Islamic Banks } \\
\text { Types }\end{array}$ & $\begin{array}{c}\text { Number of } \\
\text { response }\end{array}$ & $\begin{array}{c}\text { Percent } \\
(\mathbf{\%})\end{array}$ & $\begin{array}{c}\text { Usable } \\
\text { responses }\end{array}$ & Percent (\%) \\
\hline 1 & Commercial Banks & 51 & 62.5 & 255 & 48 \\
2 & Banking unit & 112 & 13.2 & 69 & 62 \\
3 & Rural banks & 207 & 24.3 & 173 & 84 \\
\hline & Total & 850 & 100 & 497 & \\
\hline \hline
\end{tabular}


Islamic commercial banks, also known as full-fledged banks, refer to a system of banking that complies with Islamic law while Islamic banking unit is a separate window within the commercial bank and offers financial products based on Islamic principles, in other words, this type of banks adopt dual banking system. Rural banks or micro banks is financial institution that accepts deposits only in the form of time deposits, savings, and/ or other forms that are equivalent and channeling the funds to societies in need of funds. The banks are usually located in remoted area or close to where people are in need.

\subsection{Variable Measurement}

In this research, the factors evaluated comprise of five soft TQM dimensions, i.e., Top Management Commitment (TMC); Customer Focus (CF); Education and Training (ET); Empowerment (EM); and Reward and Recognition (RR). The outcome variable in this study is Job Satisfaction while the moderator is workplace spirituality.

A tool created by Zhang et al. (2000) was used as the instrument to measure soft TQM dimensions. Top Management Commitment (TMC) was measured with seven items such as "High leadership enables staff to resolve performance issues" and "High leadership takes an active part in the quality management and enhancement system". Reward and Recognition (RR) was evaluated using tools developed by Zhang et al. (2000) and Boon Ooi et al. (2007). There were six items used to measure the variable such as : "All proposals shall be adequately paid for in money and kind" and "Premises and punishments of employees shall be conveyed" (Zhang, Waszink, \& Wijngaard, 2000)

Education and Training (ET) consisted of seven items. Examples of the items used included: "Employees are taught how to employ performance leadership techniques "and" Train employees throughout the business on performance and customer service. Empowerment (EM) was measured using seven questions. For example, "I am accountable for my job," and "I can readily obtain collaboration from my Superior when required." Meanwhile Customer Focus (CF) also consist of seven elements such as: "We are constantly constructing and maintaining a client-orientated society" and "Customer concentrate and value drive day-to-day activities".

Job satisfaction was gauged using tools developed by Boon Ooi et al. (2007). There were seven elements in this tool. Examples include: "I am pleased with the advertising possibilities" and "I am pleased with the performance sensation I receive from work." A tool created by Allport and Ross (1967) which later evaluated by Oler (2004) and Milliman et al. (2003) was adopted to measure workplace spirituality (WS). There are 20 items in this tool. Examples of these include: "I felt good about the organization's principles" and "The organization is concerned if my mind is energetic."

The responses to these factors were in the scale and spectrum of seven Likert points (1) "strongly disagree" to (7) "strongly agree." The two types of scale used in this study consist of nominal and interval scale. The nominal scale was employed to quantity the demographic factors, while interval scale was meant to assess all items in the questionnaires other than the demographic factors. 
Validity test was performed using exploratory factor analysis. Meanwhile reliability test was performed using Cronbach-Alpha.

\subsection{Data Analysis}

The data was analyzed at three levels: univariate, bivariate and multivariate analysis. Outlier test for each variable was performed to avoid data abnormalities and measurements errors (Hair et al., 2010). The next step was the classical assumption test which consisted of the normality assumption, multicollinearity, and heteroscedasticity tests. Authors used Kolmogrov-Smirnov to test the normality of the data (The Kolmogorov-Smirnov $\mathrm{Z} \leq \mathrm{Z}$ table or the Asymp.Sig (2 tailed) $>\alpha$. Meanwhile, the Variance Inflation Factor score was used to assessed the existence of multicollinearity in the data, with the tolerance value of 0.10 or VIF score above 10 (Hair et al., 2010).

The hierarchical analysis of regression with interaction model was adopted to determine whether spirituality in the workforce acted as moderator on the proposed model. The Interaction test is a special application of multiple regressions which contain interactions between different variables, (two or more variables are multiplied). The equation contains both measurable variables and the moderating variable. The p-value of the moderating regression should be considered considerably lower than the alpha or $t$ ratio than t-table or t-statistics (Hair et al., 2010). Hierarchical regression builds a framework for model comparison by building up several regression models through sequencing steps (Tabachnick \& Fidell, 2007). The analysis phases are as follows:

Equation for model 1:

$$
J S=\propto+\beta_{1} T M C+\beta_{2} R R+\beta_{3} E T+\beta_{4} E M+\beta_{5} C F+\varepsilon
$$

Equation for model 2:

$$
J S=\propto+\beta_{1} T M C+\beta_{2} R R+\beta_{3} E T+\beta_{4} E M+\beta_{5} C F+\beta_{6} W S+\varepsilon
$$

Equation for model 3:

$$
\begin{aligned}
J S & =\propto+\beta_{1} T M C+\beta_{2} R R+\beta_{3} E T+\beta_{4} E M+\beta_{5} C F+\beta_{6} W S+\beta_{7} T M C * W S \\
& +\beta_{8} R R * W S+\beta_{9} E T * W S+\beta_{10} E M * W S+\beta_{11} C F * W S+\varepsilon
\end{aligned}
$$

\section{RESULTS AND DISCUSSION}

\subsection{Sample Description}

Table 2 demonstrates the classification of participants centered on four categories: age, sex, level of education, and job experience. Vast majority of the participants were aged $25-40(67.80 \%)$, the remaining $28.8 \%$ were below 25 and $3.4 \%$ were above 40 years. The respondents were male dominants and most respondents were university graduate. In terms of their employment length, most respondents $(96.2 \%)$ had been with the bank for less than ten years. 
Table 2: Respondents' Demographic Factors

\begin{tabular}{lccc}
\hline \multirow{2}{*}{ Demographic } & Categories & \multicolumn{2}{c}{ Overall } \\
\cline { 2 - 4 } & & Frequencies & Percent \\
\hline Age & Less than 25 years & 143 & 28.8 \\
& $25-40$ years & 337 & 67.8 \\
& $41-56$ years & 17 & 3.4 \\
\hline Gender & Male & 280 & 56.3 \\
& Female & 217 & 43.7 \\
\hline Employment length & Less than 10 years & 478 & 96.2 \\
& 10-20 years & 17 & 3.4 \\
& more than 20 years & 2 & 0.4 \\
\hline Education level & Senior High & 67 & 13.5 \\
& Diploma & 50 & 10.1 \\
& Bachelor \& above & 380 & 76.5 \\
\hline \hline
\end{tabular}

\subsection{Validity and Reliability test}

Exploratory factor analysis with varimax rotation was used to test the validity of all items used to measure the constructs. The result indicated that the factor loading exceeded the value of 0.6. Hence, they were all retained for further study. The Kaiser-Meyer-Olkin of Sample Adequacy (KMO) value was 0.944, which was above the benchmark value of 0.6 (Kaiser, 1974). The Bartlet's Test for the items correlation matrix was highly significant $(\mathrm{p}<.000)$ with Chi-square value of 7616.625 in supporting the factorability of correlation matrix. The reliability test was performed using the Cronbach's alpha with the values range from 0.7640 to 0.9297 . Since the reliability $(\alpha)$ value were above 0.70 , all items are considered reliable.

\subsection{Descriptive Statistic}

Table 3 indicated the average score (mean) and standard deviation and the interrelationship among variables.

Table 3: Descriptive Statistic of Variables

\begin{tabular}{|c|c|c|c|c|c|c|c|c|c|}
\hline No & Variables & Mean & Std.Dev & 1 & 2 & 3 & 4 & 5 & 6 \\
\hline \multirow[t]{2}{*}{1.} & Top Management & & & & & & & & \\
\hline & $\begin{array}{l}\text { Commitment } \\
\text { (TMC) }\end{array}$ & 4.91 & 0.739 & - & & & & & \\
\hline 2. & $\begin{array}{l}\text { Customer Focus } \\
\text { (CF) }\end{array}$ & 6.60 & 1.272 & $0.486^{*}$ & - & & & & \\
\hline 3. & $\begin{array}{l}\text { Education and } \\
\text { Training (ET) }\end{array}$ & 5.68 & 0.882 & $0.698^{*}$ & $0.598^{*}$ & - & & & \\
\hline
\end{tabular}




\begin{tabular}{cccccccccc}
\hline \hline No & \multicolumn{1}{c}{ Variables } & Mean & Std.Dev & $\mathbf{1}$ & $\mathbf{2}$ & $\mathbf{3}$ & $\mathbf{4}$ & $\mathbf{5}$ & $\mathbf{6}$ \\
\hline 4. & $\begin{array}{l}\text { Empowerment } \\
(\mathrm{EM})\end{array}$ & 4.56 & 0.664 & $0.601^{*}$ & $0.617^{*}$ & $0.737^{*}$ & - & & \\
\hline 5. & $\begin{array}{l}\text { Reward and } \\
\text { Recognition (RR) }\end{array}$ & 5.80 & 0.847 & $0.678^{*}$ & $0.515^{*}$ & $0.755^{*}$ & $0.649^{*}$ & - & \\
\hline 6. & $\begin{array}{l}\text { Job Satisfaction } \\
(\mathrm{JS})\end{array}$ & 4.15 & 1.011 & $0.274^{*}$ & $0.230^{*}$ & $0.276^{*}$ & $0.228^{*}$ & $0.239^{*}$ & - \\
\hline 7. & $\begin{array}{l}\text { Work Spirituality } \\
\text { (WS })\end{array}$ & 3.70 & 4.516 & $0.444^{*}$ & $0.368^{*}$ & $0.500^{*}$ & $0.522^{*}$ & $0.498^{*}$ & $0.237^{*}$ \\
\hline \hline
\end{tabular}

Note: $* \mathrm{p}<0.01$

The highest mean score was on customer focus (6.60), followed by reward and recognition (5.80), education and training (5.68), top management commitment (4,91) and Empowerment (4.56). In addition, respondents were moderately satisfied with their job (4.15) with average spirituality score of 3.70. All soft TQM dimensions correlate positively with job satisfaction and workplace spirituality. The highest correlation was between top management commitment and education and training $(\mathrm{r}=0.698 ; \mathrm{p}<0.01)$. The correlation between job satisfaction and workplace spirituality was also positively significant $(r=0.237 ; \mathrm{p}<0.01)$.

\subsection{Hypothesis Testing}

Before proceed to the regression analysis, authors conducted the classical assumptions tests. There were no major issues associated with the normality and outlier testing. Therefore, none of the assumptions were violated in this case.

To test the hypothesis, authors employed a three stage hierarchical multiple regression. In the first stage, regression analysis was performed on the relationship between the five dimensions of soft TQM and job satisfaction. The model was considered fit and statistically significant with $\mathrm{F}$ statistic of 286.310 which was greater than F-table of 2.237 with sig value of 0.000 . Therefore, the hypothesis was supported. The adjusted $\mathrm{R}^{2}$ value of 0.749 indicating that Soft TQM explained 74.9 $\%$ of the variation in Islamic banks' employees' job satisfaction. In this model, reward and recognition (RR) appeared to be the most influential soft TQM dimension by possessing the highest standardized beta coefficient of 0.272 .

The second model added workplace spirituality, as a predictor of job satisfaction, into the first model. As a result, the R2 value proliferated from $75.1 \%$ to $78.9 \%$, with sig.value below $<0.001$. In the following stage, the interaction terms between soft TQM dimensions and workplace spirituality were included into the third model. The additional variance was also significant in the interaction terms of $10.4 \%$.

Table 4 illustrates the results of soft TQM's dimensions immediate and moderating impacts on job satisfaction. 
Table 4: Hierarchical Regression Analysis

\begin{tabular}{|c|c|c|c|}
\hline & $\begin{array}{l}\text { Std Beta } \\
\text { (Model 1) }\end{array}$ & $\begin{array}{l}\text { Std. Beta } \\
\text { (Model 2) }\end{array}$ & $\begin{array}{l}\text { Std. Beta } \\
\text { (Model 3) }\end{array}$ \\
\hline \multicolumn{4}{|l|}{ Predictor Variables: } \\
\hline Top Management Commitment (TMC) & $0.231^{* * *}$ & $0.198^{* * *}$ & $1.260^{* * *}$ \\
\hline Reward and Recognition (RR) & $0.272^{* * *}$ & $0.269^{* * *}$ & $1.524^{* * *}$ \\
\hline Education and Training (ET) & $0.211^{* * *}$ & $0.199^{* * *}$ & $2.044^{* * *}$ \\
\hline Empowerment (EM) & $0.181^{* * *}$ & $0.096^{* * *}$ & 0.473 \\
\hline Customer Focus (CF) & $0.164^{* * *}$ & $0.136^{* * *}$ & $1.155^{* *}$ \\
\hline \multicolumn{4}{|l|}{ Moderating Variables } \\
\hline Workplace Spiritual Values (WSV) & & $0.240^{* * *}$ & $3.879^{* * *}$ \\
\hline \multicolumn{4}{|l|}{ Interaction terms } \\
\hline TMC*WS & & & $1.685^{* *}$ \\
\hline $\mathrm{RR} * \mathrm{WS}$ & & & $1.753^{* * *}$ \\
\hline ET*WS & & & $2.979^{* * *}$ \\
\hline EM*WS & & & 0.998 \\
\hline $\mathrm{CF}^{*} \mathrm{WS}$ & & & $1.572^{* *}$ \\
\hline $\mathrm{R}^{2}$ & 0.751 & 0.789 & 0.893 \\
\hline Adjusted $\mathrm{R}^{2}$ & 0.749 & 0.786 & 0.891 \\
\hline $\mathrm{R}^{2}$ Change & 0.751 & 0.038 & 0.104 \\
\hline F Change & $286.310^{* * *}$ & $85.009^{* * *}$ & $91.365^{* * *}$ \\
\hline
\end{tabular}

Note: ${ }^{*} \mathrm{p}<0.10 ;{ }^{* *} \mathrm{p}<0.05 ;{ }^{* * *} \mathrm{p}<0.01$

The most common method of determining the moderating effect of variables was interaction analysis. The result of moderating effect testing revealed that two of the interaction terms were significant at the level of confidence of $1 \%(\alpha=0.01)$. The two terms were reward and recognition*workplace spirituality and education/training*workplace spirituality. Meanwhile, the other two terms, namely top management commitment*workplace spirituality and customer focus*workplace spirituality were significant at confidence level of $5 \%(\alpha=0.05)$. These findings confirmed the moderating role of workplace spirituality on the relationship between those four soft TQM dimensions with job satisfaction. Implying that the relationships between the soft TQM dimensions with job satisfaction was higher as employees level of spirituality raised. The interaction test of empowerment*workplace spirituality revealed otherwise.

To provide additional analysis on the role of workplace spirituality, authors used graphical plotting. Workplace spirituality was split into two categories, high and low. The split was made by comparing the mean score with the media. The respondents possessing average spirituality score above median is categorized as high and vice versa. The interaction of soft TQM dimensions and job satisfaction were then analyzed at each spirituality level. 
Figure 2: Interaction of Spirituality, Soft TQM and Job Satisfaction

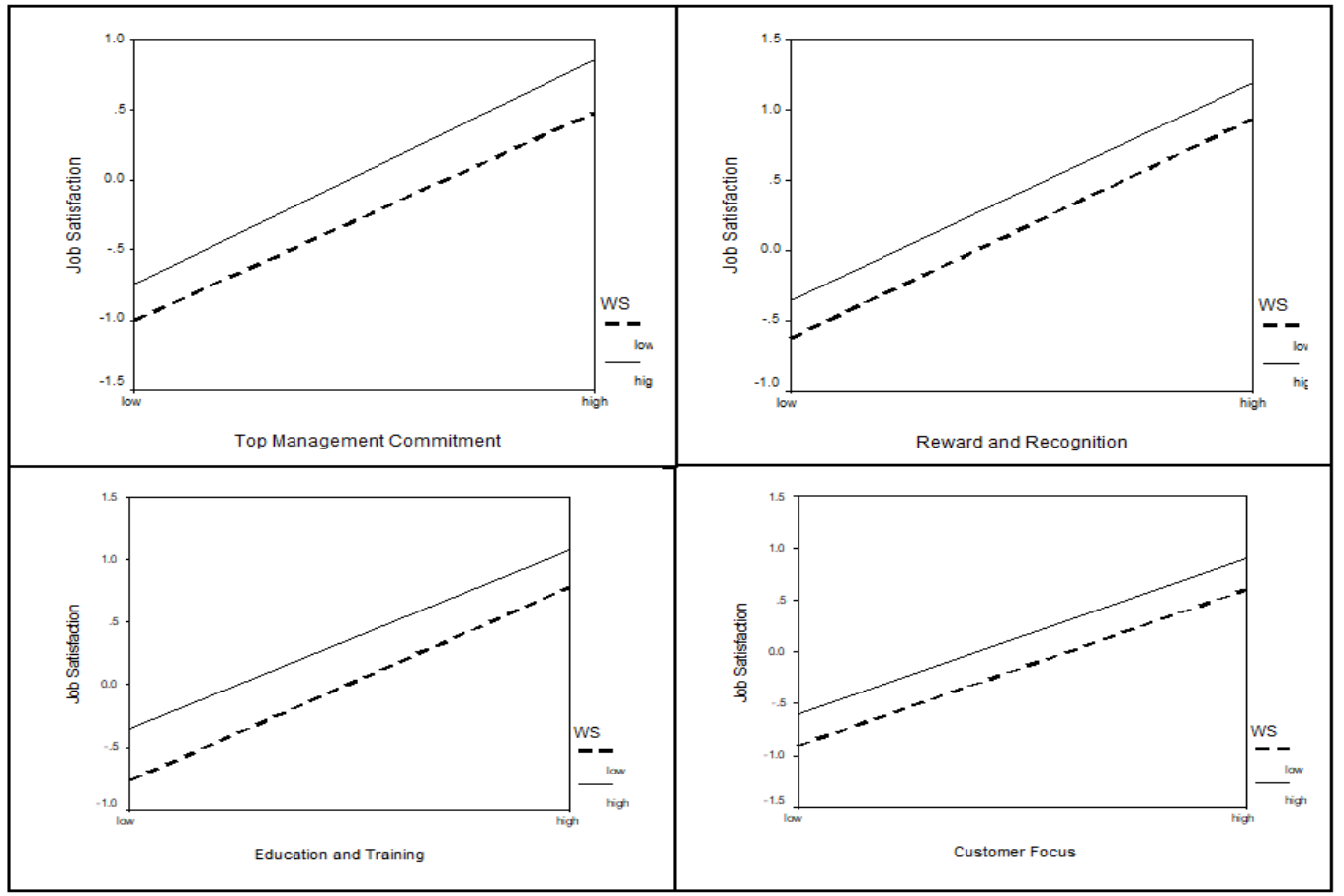

Figure 2 exhibits the favorable connection between each dimensions of soft TQM, except empowerment, with job satisfaction being moderated by workplace spirituality. The graph pattern of employees with high level of workplace spirituality was similar to that of employees with low spirituality. The graph analysis confirmed the moderating role of workplace spirituality. For example, the chart depicts the moderating function of spirituality in the favorable connection between top management commitment and job satisfaction. The fulfillment of staff with elevated spirituality on the workforce was significantly greater than that of the lower one. Therefore, these findings confirmed that spirituality at work serve as stronger a moderator on the relationship. Likewise, looking on the relationship between customer focus, workplace spirituality and job satisfaction, those employees with higher level of spirituality at works, exhibit greater proliferation of customer focus as well as satisfaction on their job. On the other hand, those employees with lower spirituality level had much looser focus on customer and hence their job satisfaction level. It was clearly indicated in the figure 3 that the slope of lines indicating high and low level of spirituality were slightly differing. Thus, spirituality was considered as quasi-moderator, since the direct influence of the moderator was statistically important at $p<0,10$. This finding endorsed the hypothesis stating that workplace spirituality moderate the relationship between soft TQM and employees' satisfaction at work.

\subsection{Discussion}

Job satisfaction is a favorable mental situation due to employees ' personal judgements on their tasks or working condition. It was evident in the study that the implementation of soft TQM had 
favorable consequences on employees' job satisfaction. Approximately $75.29 \%$ of staff of Islamic banks felt satisfied with their jobs and $24.71 \%$ of the staffs felt that their work was deceptive. Moreover, $79.90 \%$ of staff are pleased with their present work, $77.30 \%$ feel satisfied with their co-workers and $77.10 \%$ are pleased with their achievements. This finding was not in line with prior research claiming on the existence of adverse connection between implementing total quality management and the job satisfaction of employees (Adawiyah, 2011; Govindan \& Ahmad, 2003; Kivimäki et al., 1997).

Our findings support the dominant views that TQM had strong association with job satisfaction. Enquiry on TQM practices in Maquiladora found that the HRM focused on TQM practice increased employee satisfaction, loyalty and organizational performance improvements (Jun, Cai, \& Shin, 2006). The study supported previous works claiming the positive impacts of soft TQM practices on employees' job satisfaction (see for example, Boselie \& Wiele, 2002; Boon Ooi, et. al. 2007; Prajogo \& Cooper, 2010; Kabak et. al., 2014). The favorable consequences of soft TQM on job satisfaction provide positive signal to every Islamic banks' leader in Indonesia to consistently and continually adopt TQM as a way to improve employees' satisfaction. Satisfied employees would display better commitment and sense of belonging at work therefore exhibiting higher productivity. Moreover, Soft TQM does not only stimulate employees' satisfaction but also enhance individual growth and development, (Prajogo \& Cooper, 2010).

Although prior study was carried out in various nations, the findings went in the similar path. The findings of the research remained the same as situated in developed countries. Indonesia is a country with its potential emerging market (Adawiyah et al., 2015). Therefore, this study enriches literatures in the field of TQM by specifically focused on the connection between the STQM and the work contentment of the Islamic banks. In comparison with past research topics, which were primarily manufacture, the Islamic bank possess distinct features, being a utility and a spiritual based entity.

The attraction-selection-attrition theory proposed that individual choose to work in organization that is harmonized their personal value, so thus the case for Islamic bank employees. Value mismatch between organization and employees that could trigger dissatisfaction that leads to higher employees' turnover. Hence spirituality value at work offer solution to synchronize organizational-employee's relationship. It is an extremely unwise choice to detached employees' spirituality while they are at work. As stated by Sauber (2003) that:

"when 'spirit' is let outside of the workplace, it seems reasonable to think that the very essence of who we are is not present at work".

There are two ways in which the social mood is aligned and individualized, including religion, emotions, actions and organizational method. Therefore, when the organization affects and accepts the conduct standards of the organization, an individual is considered good and sustainable (Cornwall, Albrecht, Cunningham, \& Pitcher, 1986). Workplace spirituality at individual level alone is not enough without supports from employee's external surroundings. An organization 
needs to incorporate spirituality into everyday activities and safeguard employee faith from religious illness assault in order to achieve favorable workplace positions. An organization needs to establish a spiritual atmosphere in which staff think comfortable at job to control their work behavior. Satisfied staff are better able to contribute to the accomplishment of organizational aims, showing that staff have great importance in the development of their companies.

By meeting workers ' spiritual requirements, companies would benefit from advantages, like improving their conduct in the shape of a powerful co-worker relationship, consistent belief and organizational principles that would have a beneficial effect on culture generally. Whilst spiritual organization, as with past results does not expressly represent religion (Ashmos \& Duchon, 2000; Chusmir \& Koberg, 1988; Rego et al., 2008), it suggests that context factors such as corporate spiritual value might affect outcomes like job satisfaction (Giacalone \& Jurkiewicz, 2003; Roundy, 2009).

This study supports prior work by Giacalone and Jurkiewicz (2003) who argued that organizations gained benefit in the form of higher employees' willingness to work. Moreover, Rego et.al (2007) encouraged the promotion of positive relations with peers manifested as group senses that is a key dimension of spirituality. Therefore it becomes obvious that organizational wellness can reinforce the interaction between staff and their fellow workers (Roundy, 2009). However, the findings were not aligning with the work of Chusmir and Koberg (1988), which negate the link between spiritual values and working-related attitudes. More research has generally shown that workplace spirituality has triggered positive attitudes and behaviors. All Islamic banks, including commercial banks, are recommended to continuously promote religious environments to ensure that organizations continue to compete in the open market.

\section{CONCLUSION}

The result of this study supports the existence workplace spirituality as moderator on the association between soft total quality management and job satisfaction. This outcome can be used as a philosophy and fundamental idea to promote positive employees' work behaviours. The concept of spirituality in the workplace should be well taken into consideration and therefore be applied at the individual, group and organizational stages. Islamic bank leaders could focus on specific aspects of the soft TQM to foster favorable work attitudes and behavior. Among prioritize dimensions of soft TQM were top management commitment, reward and recognition, education and training as well as customers' focus. For a better human sides of TQM practices, leaders should provide various kind of supports to employees. The support can be in the material forms or other substances.

Theoretically, this study enhance literature in the field of TQM especially on its implementation in Islamic banks, institutions with strong religious value. At the practical level, employees' favorable attitudes work parallel with their level of spirituality. Stronger connection between customer focus and job satisfaction occur when an employees' level of spirituality is high. Therefore, managers need to provide work ambience that nurture spirituality. Islamic banks institution in Indonesia impose daily programs to nurture employees' spirituality at work. Similar to the human physical power, spiritual state also has energy resources and several complications that is destructive in nature. The spiritual force shall alight a believer strong and spiritually supportive when well 
understood and nurtured. To persistently alight employees' spirituality, an organization should constantly employ a well-designed spiritual platform.

This study is not without limitations. Some of the drawbacks that could possibly be improved by future studies are: first, the study has a narrow scope of sample because it only focus on Islamic banks operating in Central Java Indonesia. To increase its generalizability, the theory can be tested in Islamic banks across nations with prominent Islamic banks practices. Second, the study was crossectional in nature therefore the result may omit some short term events. Likewise, there is a possibility of bias issues affecting the result. To overcome the problem, futures studies may adopt longitudinal research design to better portray the variables' pattern of movements overtime. Longer observation period allows for better understanding on the cause and effect relationships among variables under study. Furthermore, more data would result in better outcomes. Third, the research model of this study can be improved by adding more moderator such as personal characteristics or traits.

\section{REFERENCE}

Adawiyah, W. R. (2011). The relationship between soft tqm and work related outcome: The moderating impact of spirituality at the workplace (Doctoral dissertation, Universiti Utara Malaysia). Retrieved from http://etd.uum.edu.my/3416/

Adawiyah. W. R. (2015). Impression management tactics, work related behavior and perceived individual performance of sales clerks: A case of Indonesia. International Journal of Applied Business and Economic Research, 13(7), 5481-5501.

Adawiyah, W. R., \& Pramuka, B. A. (2012). The relationship between soft TQM and organizational citizenship behavior: A case of Islamic Banks in Indonesia. International Review of Sciences and Humanities, 2(2), 213-226.

Adawiyah, W. R., \& Pramuka. B. A. (2017). Scaling the notion of Islamic spirituality in the workplace. Journal of Management Development, 36(7), 877-898.

Adawiyah, W. R., Pramuka, B. A., Najmudin, \& Jati, D. P. (2015). Green supply chain management and its impact on construction sector small and medium enterprises (SMEs) performance: A case of Indonesia. International Business Management, 9(6), 1010-1024.

Adebanjo, D., \& Kehoe, D. (1999). An investigation of quality culture development in UK industry. International Journal of Operations \& Production Management, 19(7), 633650. https://doi.org/10.1108/01443579910271656

Ashmos, D. P., \& Duchon, D. (2000). Spirituality at work: A conceptualization and measure. Journal of Management Inquiry, 9(2), 134-145.

Boon, O. K., Abu Bakar, N., Arumugam, V., Vellapan, L., \& Loke, A. K. Y. (2007). Does TQM influence employees' job satisfaction? An empirical case analysis. International Journal of Quality \& Reliability Management, 24(1), 62-77. https://doi.org/10.1108/02656710710720330 
Boselie, P., \& van der Wiele, T. (2002). Employee perceptions of HRM and TQM, and the effects on satisfaction and intention to leave. Managing Service Quality: An International Journal, 12(3), 165-172. https://doi.org/10.1108/09604520210429231

Cacioppe, R. (2000). Creating spirit at work: Re-visioning organization development and leadership - Part II. Leadership \& Organization Development Journal, 21(2), 110 119. https://doi.org/10.1108/01437730010318200

Chusmir, L. H., \& Koberg, C. S. (1988). Religion and attitudes toward work: A new look at an old question. Journal of Organizational Behavior, 9(3), 251-262.

Cornwall, M., Albrecht, S. L., Cunningham, P. H., \& Pitcher, B. L. (1986). The dimensions of Religiosity: A conceptual model with an empirical test. Review of Religious Research, 27(3), 226-244. https://doi.org/10.2307/3511418

Dale, B. G., Cooper, C. L., \& Wilkinson, A. (1997). Managing quality and human resources: A guide to continuous improvement: Blackwell.

Ehigie, B. O., \& Akpan, R. C. (2006). Roles of personality attributes in the practice of total quality management. Individual Differences Research, 4(2), 78-105.

Eniola, A. A., Olorunleke, G. K., Akintimehin, O. O., Ojeka, J. D., \& Oyetunji, B. (2019). The impact of organizational culture on total quality management in SMEs in Nigeria. Heliyon, 5(8), 1-10. doi: https://doi.org/10.1016/j.heliyon.2019.e02293

Fry, L. W., Vitucci, S., \& Cedillo, M. (2005). Spiritual leadership and army transformation: Theory, measurement, and establishing a baseline. The leadership quarterly, 16(5), 835862.

Giacalone, R. A., \& Jurkiewicz, C. L. (2003). Handbook of workplace spirituality and organizational performance: Me Sharpe.

Govindan, S., \& Ahmad, Z. (2003). Managing manufacturing professional's job satisfaction via human resource management practices. Paper presented at the The Fifth Asian Academy of Management Conference: Conference Proceedings.

Hair, J. F., Black, W. C., \& Babin, B. J. (2010). Multivariate data analysis: A global perspective. New Jersey, Pearson Prentice Hall.

Hari Adi, P. \& Adawiyah, W. R. (2018). The impact of religiosity, environmental marketing orientation and practices on performance: A case of Muslim entrepreneurs in Indonesia. Journal of Islamic Marketing, 9(4), 841-862. https://doi.org/10.1108/JIMA09-2016-0067.

Helmy, I., Adawiyah, W. R., \& Banani, A. (2019). Linking psychological empowerment, knowledge sharing, and employees' innovative behavior in SMEs. The Journal of Behavioral Science, 14(2), 66-79.

Hendricks, K. B., \& Singhal, V. R. (1996). Quality awards and the market value of the firm: An empirical investigation. Management science, 42(3), 415-436.

Jun, M., Cai, S., \& Shin, H. (2006). TQM practice in maquiladora: Antecedents of employee satisfaction and loyalty. Journal of Operations Management, 24(6), 791-812.

Kabak, K. E., Şen, A., Göçer, K., Küçüksöylemez, S., \& Tuncer, G. (2014). Strategies for employee job satisfaction: A case of service sector. Procedia-Social and Behavioral Sciences, 150, 1167-1176.

Kaiser, H. F. (1974). An index of factorial simplicity. Psychometrika, 39(1), 31-36. doi: $10.1007 / \mathrm{BF} 02291575$ 
Kivimäki, M., Mäki, E., Lindström, K., Alanko, A., Seitsonen, S., \& Järvinen, K. (1997). Does the implementation of total quality management (TQM) change the wellbeing and workrelated attitudes of health care personnel? Study of a TQM prize-winning surgical clinic. Journal of Organizational Change Management, 10(6), 456-470. https://doi.org/10.1108/09534819710190085.

Kristof-Brown, A. L., Zimmerman, R. D., \& Johnson, E. C. (2005). Consequences of individuals'fit at work: A meta-analysis of person-job, person-organization, person-group, and personsupervisor fit. Personnel Psychology, 58(2), 281-342.

Latif, Y., Iqbal, P., ur Rehman, S., Latif, M. Y., \& ur Rehman, M. S. (2014). Important TQM implementation contributors in service oriented organization like banks in Pakistan. MAGNT Research Report, 2(5), 199-133.

Milliman, J., Czaplewski, A. J., \& Ferguson, J. (2003). Workplace spirituality and employee work attitudes: An exploratory empirical assessment. Journal of organizational change management, 16(4), 426-447.

Morrow, P. C. (1997). The measurement of TQM principles and work-related outcomes. Journal of Organizational Behavior: The International Journal of Industrial, Occupational and Organizational Psychology and Behavior, 18(4), 363-376.

Morrow, P. C., McElroy, J. C., \& Scheibe, K. P. (2011). Work unit incivility, job satisfaction, and total quality management among transportation employees. Transportation Research Part E: Logistics and Transportation Review, 47(6), 1210-1220. doi: https://doi.org/10.1016/j.tre.2011.03.004

Othman, I., Norfarahhanim Mohd Ghani, S., \& Woon Choon, S. (2019). The total quality management (TQM) journey of Malaysian building contractors. Ain Shams Engineering Journal. doi: https://doi.org/10.1016/j.asej.2019.11.002 (article in press)

Ouyang, Y. Q., Zhou, W. B., Xiong, Z. F., Wang, R., \& Redding, S. R. (2019). A web-based survey of marital quality and job satisfaction among Chinese nurses. Asian Nursing Research, 13(3), 216-220. doi: https://doi.org/10.1016/j.anr.2019.07.001

Powell, T. C. (1995). Total quality management as competitive advantage: A review and empirical study. Strategic Management Journal, 16(1), 15-37.

Prajogo, D. I., \& Cooper, B. K. (2010). The effect of people-related TQM practices on job satisfaction: A hierarchical model. Production Planning and Control, 21(1), 26-35.

Pramuka, B. A., \& Adawiyah, W. R. (2012). The human related dimensions of TQM practise in service settings. American International Journal of Contemporary Research, 2(1), 24131.

Rahman, S. U., \& Bullock, P. (2005). Soft TQM, hard TQM, and organizational performance relationships: an empirical investigation. Omega, 33(1), 73-83.

Rego, A., Pina E Cunha, M., \& Oliveira, M. (2008). Eupsychia revisited: The role of spiritual leaders. Journal of Humanistic Psychology, 48(2), 165-195.

Roundy, P. T. (2009). Work and religion: Artificial dichotomy or competing interests. International Journal of Human and Social Sciences, 4(5), 311-317.

Schneider, B. (1987). The people make the place. Personnel psychology, 40(3), 437-453.

Schonberger, R.J. (1994). Human resource management lessons from a decade of total quality management and reengineering, California Management Review, 36(4), 109-23. 
Sholikhah, Z., Wang, X. \& Li, W. (2019). The role of spiritual leadership in fostering discretionary behaviors: The mediating effect of organization based self-esteem and workplace spirituality. International Journal of Law and Management, 61(1), 232249. https://doi.org/10.1108/IJLMA-04-2018-0081

Slovin, E. (1960). Slovin's formula for sampling technique. Statistics How To. Retrieved from https://www.statisticshowto.com/how-to-use-slovins-formula/

Soltani, E. (2003), Towards a TQM-driven HR performance evaluation: an empirical study. Employee Relations, 25(4), 347-370. https://doi.org/10.1108/01425450310483370

Soltani, E., Gennard, J., van der Meer, R. B. \& Williams, T. (2004). HR performance evaluation in the context of TQM: A review of the literature. International Journal of Quality \& Reliability Management, 21(4), 377-396. https://doi.org/10.1108/02656710410530082

Strack, G., Fottler, M. D., Wheatley, M. J., \& Sodomka, P. (2002). Spirituality and effective leadership in healthcare: Is there a connection?/commentaries/replies. Frontiers of health services management, 18(4), 3-18.

Tabachnick, B., \& Fidell, L. (2007). Using multivariate statistics, 5th ed New York. NY: Allyn and Bacon.

Törnroos, M., Jokela, M., \& Hakulinen, C. (2019). The relationship between personality and job satisfaction across occupations. Personality and Individual Differences, 145, 82-88.

Waddock, S. A. (1999). Linking community and spirit: A commentary and some propositions. Journal of organizational change management.

Warsito, C., Sholikhah, A., Adawiyah, W. R., \& Setyanto, R. P. (2020). Antecedents of consumers' decision for halalmart shopping: The moderating role of family religious commitment. Humanities and Social Sciences Reviews, 8(1), 152-164. doi: 10.18510/hssr.2020.8122

Wihuda, F., Kurniawan, A. A., Kusumah, A. I., \& Adawiyah, W. R. (2017). Linking empowering leadership to employee service innovative behavior: A study from the hotel industry. Turizam: međunarodni znanstveno-stručni časopis, 65(3), 294-313.

Zhang, Z., Waszink, A., \& Wijngaard, J. (2000). An instrument for measuring TQM implementation for Chinese manufacturing companies. International Journal of Quality \& Reliability Management. https://doi.org/10.1108/02656710010315247 